\title{
ON THE PLACEMENT AND MASS OF AVALANCHE EXPLOSIVES: EXPERIENCE WITH HELICOPTER BOMBING AND PREPLANTED CHARGES
}

\author{
by \\ R. Perla \\ (National Hydrology Research Institute, Environment Canada, Ottawa K1A 0E7, Canada) \\ and $\mathrm{K}$. Everts \\ (Parks Canada, Environment Canada, Banff, Alberta TOL OCO, Canada)
}

\begin{abstract}
Snow avalanches threatening the road to the Sunshine ski area in Banff National Park, Alberta, Canada, are controlled by helicopter bombing and preplanted explosives. The effectiveness of these methods is evaluated using two ratios: avalanche points/bomb and avalanche points/kilogram of explosive, where avalanche points are computed on a scale of 1 to 5, according to size. Analysis of 74 helicopter missions shows a sianificant increase in avalanche points/bomb with increasing bonb mass. Comparison of helicopter bombing (near-surface detonations) with preplanted charges (ground detonation) shows that ground detonations are at least as effective as bombs detonated just below the snow surface.
\end{abstract}

\section{INTRODUCTION}

In many mountainous areas throughout the world the avalanche hazard is controlled by using explosives to bring about artificial release. For example. each year in North America a variety of methods are used to detonate $\sim 10^{5}$ explosive charges on slopes with suspected instability (Mellor 1968, 1973, Perla and Martinelli 1976, Perla 1978[a], [b]. Despite the widespread use of explosives in avalanche hazard control, very little is known about the best choice of mass and placement of an explosive to release a given slope.

In the few comprehensive studies to date, Gubler $(1976,1977[a]$ and $[b], 1978)$ reports on the attenuation of explosive energy in a level plot of snow as a function of explosive amount, position, and speed. His tests indicate that a charge detonated at or above the surface of the snow has a much greater range compared to a charge buried in the snow since the energy attenuation is relatively large within the snow. Gubler (1978) presents data from Switzerland and Austria confirming the advantage of air propagation in the blasting of avalanche slopes, and recent experience at North Anerican ski areas suggests that there inay be some advantage to above-surface detonations (personal communications from L FitzGerald at Snowbird, Utah, and C Israelson at Lake Louise, Alberta). Thus, there is growing evidence that explosive effectiveness depends on the position of the explosive with respect to the snow surface. Detonation above the snow surface is not practical in most situations. The vast majority of explosives are hand-thrown or launched against the snow surface. If the snow surface is relatively hard, the explosive may rest directly on it during detonation, but more generally the charge penetrates into the snow and detonates at about 0.1 to $1.0 \mathrm{~m}$ below the surface.

Certain types of artillery rounds have basemounted fuses which require a solid impact against the surface of the ground for reliable activation. Also, in some areas where zones suitable for starting avalanches are inaccessible, a practical alternative is to preplant explosives on the ground during autumn for subsequent detonation with coded radio signals. It is not known how a charge detonated at the snowground interface compares in its effectiveness to one detonated just below the surface.

A related question concerns the effectiveness gained by increasing or decreasing the mass of explosive. Gubler found that the energy delivered to his transducers on a level plot varied as the square root of explosive mass. To date, there are no studies which confirm that square root scaling applies to the failure and release of inclined snow slopes. Moreover, there are no objective guidelines for matching the mass of an explosive to a potentially unstable slope.

One difficulty in answering the above questions is the large number of variables associated with the nature of the terrain and with meteorological factors, as well as practical constraints that are present in any study of the release of avalanche slopes. Another difficulty is the lack of a method of evaluating what constitutes an "effective" response to blasting an avalanche slope. Our present study which employs ten years of data on explosive control illustrates some of these difficulties. In spite of large statistical scatter, we will reach some modest conclusions about explosive position and mass.

AVALANCHE CONTROL DATA

The access road to the Sunshine ski area in Banff National Park, Alberta, is threatened by 14 
avalanche paths which descend vertically $\sim 1000 \mathrm{~m}$ froin starting zones $\sim 10^{4}$ to $\sim 10^{5} \mathrm{~m}^{2}$ in area. Most of the starting zones are inaccessible to artillery or avalanche control teams, and transmission of explosives by cable car to detonating positions above the snow surface was judged impractical considering the vertical distance from valley bottom. Helicopter bombing was introduced in 1968, and self-consistent record-keeping of missions began with the winter 1970-71. A total of 74 helicopter missions was flown in the period 1970-71 to 1981-82. Beginning in the winter of 1974-75, helicopter bonbing was supplemented with explosives detonated by VHF radio, preplanted in the starting zone during the autumn in accordance with techniques described by Everts and Laidlaw (1978). A total of 38 missions based on preplanted explosives was completed during the winters 1974-75 to 1981-82, but not necessarily on the same days as helicopter missions flown during those years.

of direct relevance to the questions posed in the introduction is that helicopter bombs detonate at or just below $(<1.0 \mathrm{~m})$ the snow surface, depending on the snow surface hardness, and always lift snow and detonation gas from heinispherical blast craters. By contrast, preplanted bombs detonate at the ground-snow interface which, in the Sunshine area, is typically 1 to $3 \mathrm{~m}$ below the snow surface depending on lateness of season and snowfall amounts. Craters are small or not observed, noise is muffled, and usually only small amounts of snow and detonation gas are thrown upwards above the snow surface. Therefore, the records of the Sunshine control missions provide a possibility for comparing nearsurface and ground detonations. In addition, the average helicopter bomb mass was varied from one mission to the next ( 1 to $16 \mathrm{~kg})$; this provides a possibility for comparing results as a function of homb mass.

All bombs contained a high percentage of trinitrotoluene (TNT), and were comparable in speed of detonation and pressure.

\section{EXPLOSIVE. EFFECTIVENESS}

Avalanche size in response to an explosion was recorded on a point scale 1 to 5 , based on the destructive capability of the avalanche as shown in Table I. The records in the present study included up to size 4 avalanches, but not size 5 , which is the extreme linit for the world's largest avalanches. From the viewpoint of field observers and record keepers, the 1 to 5 scale of Table I is easy to use, will give self-consistent scores since observers will rarely disagree by inore than one point, and has direct relevance to hazard evaluation. However, it is far from the best measure of avalanche response to an explosive blast. Perhaps it would be preferable to

\section{TABLE I. METHOD OF ASSIGNING AVALANCHE POINTS}

Avalanche points

\section{Observation}

Sluff. Could not bury or injure a skier.

Small avalanche. Could bury or injure a skier.

Medium avalanche. Could destroy a building or car.

Large avalanche. Could destroy a village or forest.

Extreme. World's largest avalanches (e.g. in Andes, Himalayas, St Elias Mountains). use area and thickness of the initial slab released by the explosive; unfortunately these data were not recorded consistently. The absence of a more direct measure of avalanche response to a blast may explain some of the high variance in our present results.

We assume that an avalanche larger than size 1 is an effective response to an explosion. The choice of this somewhat arbitrary threshold could cause some of our high variance; however, the threshold should not be selected to minimize variance. In our opinion, a non-release or a sluff (size 1) is an ineffective. response (this is open to controversy). For any number of bombs or missions we can therefore define two ratios which characterize the effectiveness of the bombs or missions: (a) the total avalanche points ( $>2$ ) divided by the total number of bombs, and (b) the total avalanche points $(>2)$ divided by the total mass of explosives in $\mathrm{kg}$.

The simpler alternative is to equate effectiveness with the number of avalanches above a threshold (size 2 in our case), without any additional size discrimination. As explained later, we found that this alternative gave a poorer correlation with bomb inass. We believe (again open to controversy) that there is a need to introduce avalanche size in the measure of explosive effectiveness.

\section{PRECIPITATION INDEX}

An important complication in any comparative study of avalanche control is the variation of meteorological variables from mission to mission. Snowfall, precipitation, temperature, and wind data were recorded daily during the mission period froin 1970 to 1982, inclusive of the months November to April. These data were used to derive indices by sumining the data back into the past from the day of the laission. Analysis was made of indices based on one-, three-, and seven-day sums of the above variables. It turned out that the precipitation (in $\mathrm{mm}$ of water) summed for the three-day period before the mission correlated most significantly $(r=0.63)$ with total avalanche points. The importance of precipitation compared to the remaining variables (snowfall, temperature, wind) is recognized in many previous studies of avalanche forecasting, which usually find higher correlations between avalanche activity and precipitation, and especially high values where explosive control is conducted during or immediately after heavy snowfall in anticipation of instability due to new snow. By contrast, in the present study missions using helicopter bombing and preplanted explosives were usually conducted during favourable weather, of ten many days after a precipitation cycle. The intent was to force instability in deep, weak layers (depth hoar) usually found in the snowpack of the Canadian Rockies, as well as the possibility of forcing release of the newly-fallen snow.

In any case, the precipitation history preceding a mission is an important variable, as we will show, and should be considered in comparing the effectiveness of missions.

\section{RESULTS: NEAR-SURFACE AND GROUND DETONATIONS}

Data frol each mission are compiled in the appendix. These data can be grouped as shown in Table II which gives a comparison of 74 helicopterbombing missions (near-surface detonations) and 38 preplanted-charge missions (ground detonations). The 74 helicopter-bombing missions are divided into two columns: 31 missions flown in the early years before the introduction of preplanted explosives, and 43 missions flown contemporaneously with the use of preplanter explosives. We draw attention to the effectiveness ratio points $/ \mathrm{kg}$ which is significantly higher for preplanted-charge missions. This follows despite a lower three-day precipitation history. We also note that the ratio points/bomb of the preplanted-charge 
TABLE II. COMPARISON OF MISSIONS USING HELICOPTER BOIBING AND PREPLANTED EXPLOSIVES

Helicopter bombing

Nov 1970 to May 1974

31

Nov 1974 to May 1982

Number of missions

Total number of bombs

Total mass of explosives $(\mathrm{kg})$

Average bomb nass $(\mathrm{kg})$

Total number of ava-

lanches (size >2)

Average avalanche size

Total avalanche points

Points/bomb

Points/kg

Average three-day precipitation history history $(\mathrm{mm})$
Preplanted explosives Nov 1974 to May 1982

$\begin{array}{rrr}453 & 609 & 100 \\ 3537 & 2369 & 537 \\ 7.81 & 3.89 & 5.37 \\ 141 & 118 & 35 \\ 3.01 & 2.60 & 2.60 \\ 424 & 307 & 91 \\ 0.936 & 0.504 & 0.910 \\ 0.120 & 0.130 & 0.169 \\ 32.5 & 23.3 & 17.1\end{array}$

missions exceeds the points/bomb of the contemporaneous helicopter-bombing missions, and even approaches the points/bomb for the earlier missions which were carried out with larger bomb masses and synchronized to much higher three-day precipitation histories. Given a snowpack where there is potential deepslab instability, we conclude from Table II that ground detonations have an effectiveness that is comparable to near-surface detonations. We only resist a stronger conclusion because of the imbalance in the total amounts of explosive, but the possibility that ground detonations are better in some circuinstances should not be dismissed.

RESULTS: BOMB MASS

From Table II it is also possible to conclude that the effectiveness ratio points/bomb increases with increasing bomb mass. Table III confirms this trend by listing helicopter-bombing and preplantedcharge missions according to average bomb mass. The trend appears to hold with the exception of a re-

versal at 4.3 and $2.0 \mathrm{~kg}$. However, an important complication is that the 3 -day precipitation histories also stratify in the same order as the bomb masses, and it is therefore necessary to separate the effect of these two variables (precipitation and bonb mass) on the points/bomb.

One method of making a separation of effects is with a two-stage regression in which the dependent variable is the points/bomb $Y$, and the two independent variables are three-day precipitation $X_{1}$ and bomb mass $X_{2}$. Table IV summarizes the statistics of $Y$, $X_{1}$, and $X_{2}$ from the 74 helicopter-bombing missions. First-stage correlations are summarized in Table $V$ which indicates that $X_{1}$ is the slightly stronger independent variable, and that the linear function of $x_{2}$ as opposed to $\left(x_{2}\right)^{2},\left(x_{2}\right)^{1 / 2}$, and $\left(x_{2}\right)^{1 / 3}$ is optimum. Because the correlations are too weak and too close to one another it is prenature to accept a linear relationship between $Y$ and $X_{2}$ in preference to, say, a square-root relationship (preferable according to Gubler's attenuation measurements) as anything more than a statistical result, given the high variance of our data.

TABLE III. MISSIONS LISTED ACCORDING TO BOMB MASS

\begin{tabular}{|c|c|c|c|c|}
\hline $\begin{array}{l}\text { Type of } \\
\text { control }\end{array}$ & $\begin{array}{l}\text { Number of } \\
\text { missions }\end{array}$ & $\begin{array}{l}\text { Average boinb } \\
\text { mass }(\mathrm{kg})\end{array}$ & Points/bomb & $\begin{array}{c}\text { Average } 3 \text {-day precipi- } \\
\text { tation history }(\mathrm{mm})\end{array}$ \\
\hline Helicopter & 11 & 10.3 & 1.06 & 33.9 \\
\hline Helicopter & 34 & 6.8 & 0.81 & 29.6 \\
\hline Helicopter & 11 & 4.3 & 0.48 & 25.6 \\
\hline Helicopter & 18 & 2.0 & 0.57 & 18.8 \\
\hline Preplanted & 23 & 6.8 & 1.09 & 16.8 \\
\hline Preplanted & 15 & 4.0 & 0.82 & 17.7 \\
\hline
\end{tabular}


TABLE IV. VARIABLES IN REGRESSION ANALYSIS OF 74 HELICOPTER-BOMBING MISSIONS

\begin{tabular}{lcccc}
\multicolumn{1}{c}{ Variable } & Symbol & Range & Mean & Standard deviation \\
\hline Points/bomb & $Y$ & $0-2.67$ & 0.74 & 0.56 \\
3-day precipitation $(\mathrm{mm})$ & $\mathrm{X}_{1}$ & $0-104$ & 27.1 & 20.1 \\
Bomb mass $(\mathrm{kg})$ & $\mathrm{X}_{2}$ & $1-16.6$ & 5.78 & 2.99 \\
$\begin{array}{l}\text { Total avalanches } \\
(>2) \text { /bomb }\end{array}$ & $\mathrm{Z}$ & $0-0.68$ & 0.26 & 0.17 \\
\hline
\end{tabular}

As noted earlier, there is the possibility that a simpler measure of effectiveness based on a total number of avalanches (above a threshold) could be used in place of $Y$. With reference to Tables IV and $V$, we found the correlation of $X_{2}$ with $Z$ ( = total number of avalanches $>2$ divided by the number of bombs) to be poorer $(r=0.27)$ than the $Y-X_{2}$ correlation. This gives partial justification for choosing $Y$ instead of $Z$ as the effectiveness measure (and dependent variable in a regression analysis).

TABLE V. CORRELATION OF VARIABLES DEFINED IN TABLE IV

$\begin{array}{lc}\text { Correlation } & r \\ Y \text { vs } X_{1} & 0.40 \\ Y \text { vs }\left(X_{1}\right)^{1 / 3} & 0.34 \\ Y \text { vs }\left(X_{2}\right)^{1 / 2} & 0.35 \\ Y \text { vs } X_{2} & 0.37 \\ Y \text { vs }\left(X_{2}\right)^{2} & 0.36 \\ Z \text { vs } X_{2} & 0.27\end{array}$

In the second stage of the regression, $X_{2}$ is correlated with the residual $Y-\left(m X_{1}+b\right)$, where in and $b$ are the respective first-stage regression constants 0.011 and 0.44 . The correlation of $x_{2}$ with the residual gives $r=0.32$, which is 10 w but none the less significant (given 74 data pairs), and proves that $Y$ indeed depends on both $X_{1}$ and $X_{2}$ despite the dominating influence of $x_{1}$. The complete two-stage regression is

$$
Y=0.011 x_{1}+0.055 x_{2}+0.196,
$$

where $r=0.47$. This regression is too poor to have predictive value, although it does suggest relative trends.

\section{CONCLUSIONS}

From our study of artificial avalanche release in the Canadian Rockies by means of either helicopter bombing or preplanted explosives we conclude (1) with respect to the effectiveness of releasing avalanches, explosives detonated at the ground-snow interface are comparable to explosives detonated just below the snow surface, and (2) the probability of avalanche release increases significantly with increasing bomb mass in the range of 1 to $16 \mathrm{~kg}$ of high explosive.

These conclusions are based on data with rather high variance (low $r$-values). Further confirmation is necessary, especially in other areas where the snowpack is thicker $(>2 \mathrm{~m})$, where instability is mostly confined to surface layers of newly fallen snow, and where explosive control is usually attempted during or immediately after periods of heavy snowfall.

It was not possible to formulate quantitative guidelines for choosing the best placement and mass of avalanche explosives because of the large number of uncontrolled variables in our data. It may always be difficult to go beyond some modest guidelines because avalanche situations differ from each other. Nevertheless, more work is needed on this interesting and challenging problem.

\section{REFERENCES}

Everts K, Laidlaw B 1978 Research and development of avalanche control methods in Banff National

Park. Canada. National Research Council. Associate Committee on Geotechnical Research. Technical Memorandum 120: 30-41

Gubler H 1976 Künstliche Auslösung von Lawinen durch Sprengungen (Zwischenbericht). Mitteilungen des Eidgenbssischen Institutes fur Schnee- und Lawinenforschung 32

Gubler H 1977[a] Artificial release of avalanches by explosives. Joumal of Glaciology 19(81): 419-429

Gubler H 1977[b] Künstliche Auslösung von Lawinen durch Sprengungen. Mitteilungen des Eidgenbssischen Institutes fur Schnee- und Lawinenforschung 35

Gubler H 1978 Künstliche Auslösung von Lawinen durch Sprengungen. Eine Anleitung für den Praktiker. Mitteilungen des Eidgenbssichen Institutes fur Schnee- und Lowinenforschung 36

Mellor M 1968 Avalanches. CRREL Monograph III-A3d

Mellor M 1973 Controlled release of avalanches by explosives. US Department of Agriculture. Forest Service. General Technical Report RM-3

Perla R 1978[a] Artificial release of avalanches in North America. Arctic and Alpine Research 10(2): 235-240

Perla R (ed) 1978[b] Avalanche control, forecasting, and safety. Canada. National Research Council. Associate Committee on Geotechnical Research. Technical Memorandum 120

Perla R, Martinelli M Jr 1976 Avalanche handbook. US Department of Agriculture. Forest Service. Agriculture Handbook 489 
APPENDIX: MISSION DATA

\begin{tabular}{|c|c|c|c|c|c|c|c|c|}
\hline \multirow{2}{*}{$\begin{array}{c}\text { Date } \\
\text { (year,month } \\
\text { day) }\end{array}$} & \multirow{2}{*}{$\begin{array}{l}\text { Total snow } \\
\text { stake } \\
\text { (m) } \star\end{array}$} & \multirow{2}{*}{$\begin{array}{l}\text { 3-day precipi- } \\
\text { tation history } \\
\qquad(\mathrm{m}) \quad \star \star\end{array}$} & \multirow{2}{*}{$\begin{array}{l}\text { Type of } \\
\text { control } \\
\star \star \star\end{array}$} & \multirow[t]{2}{*}{$\begin{array}{l}\text { Number of } \\
\text { bombs }\end{array}$} & \multirow{2}{*}{$\begin{array}{l}\text { Total mass of } \\
\text { explosives } \\
(\mathrm{kg})\end{array}$} & \multicolumn{3}{|c|}{$\begin{array}{c}\text { Number of ava- } \\
\text { lanches }\end{array}$} \\
\hline & & & & & & size 2 & size 3 & size \\
\hline $\begin{array}{l}70 / 12 / 4 \\
71 / 1 / 16\end{array}$ & 1.00 & 20 & H & 10 & 68 & 0 & 4 & 1 \\
\hline $\begin{array}{l}71 / 1 / 16 \\
71 / 1 / 31\end{array}$ & 1.60 & 16 & H & 15 & 102 & 1 & 4 & 1 \\
\hline $\begin{array}{l}71 / 1 / 31 \\
71 / 2 / 26\end{array}$ & 2.40 & 104 & H & 19 & 129 & 3 & 1 & 9 \\
\hline $\begin{array}{l}71 / 2 / 26 \\
71 / 3 / 31\end{array}$ & 2.30 & 23 & H & 18 & 122 & 2 & 3 & 0 \\
\hline $\begin{array}{l}71 / 3 / 31 \\
71 / 11 / 22\end{array}$ & 2.60 & 43 & H & 20 & 136 & 0 & 3 & 1 \\
\hline $\begin{array}{l}71 / 12 / 18 \\
71 / 12 / 22\end{array}$ & 1.00 & 13 & H & 17 & 116 & 0 & 3 & 0 \\
\hline $\begin{array}{l}71 / 12 / 22 \\
71 / 12 / 25\end{array}$ & 1.18 & 18 & H & 14 & 95 & 0 & 5 & 0 \\
\hline $71 / 12 / 25$ & 1.41 & 34 & H & 12 & 82 & 0 & 5 & 0 \\
\hline $\begin{array}{l}72 / 1 / 10 \\
72 / 1 / 17\end{array}$ & 1.48 & 20 & H & 13 & 102 & 0 & 3 & 1 \\
\hline $72 / 1 / 17$ & 1.65 & 10 & H & 15 & 116 & 1 & 0 & 1 \\
\hline $72 / 1 / 21$ & 1.92 & 37 & $\mathrm{H}$ & 18 & 163 & 0 & 1 & 1 \\
\hline $72 / 1 / 23$ & 1.95 & 66 & $\ddot{H}$ & 18 & 299 & 0 & 1 & 2 \\
\hline $72 / 2 / 16$ & 2.18 & 31 & H & 13 & 116 & 0 & 2 & 1 \\
\hline $72 / 2 / 17$ & 2.10 & 29 & H & 5 & 48 & 0 & 2 & 0 \\
\hline $72 / 2 / 29$ & 2.25 & 25 & H & 20 & 136 & 0 & 7 & 2 \\
\hline $72 / 3 / 1$ & 2.75 & 50 & H & 3 & 48 & 0 & 0 & 2 \\
\hline $72 / 3 / 10$ & 2.70 & 31 & H & 18 & 122 & 0 & 2 & 0 \\
\hline $72 / 12 / 2$ & 0.80 & 44 & H & 15 & 102 & 5 & 1 & 0 \\
\hline $72 / 12 / 27$ & 1.10 & 60 & H & 18 & 136 & 0 & 5 & 3 \\
\hline $73 / 1 / 15$ & 1.10 & 12 & H & 10 & 68 & 2 & 2 & 0 \\
\hline $73 / 1 / 26$ & 1.38 & 29 & H & 16 & 109 & 4 & 2 & 0 \\
\hline $73 / 3 / 11$ & 1.60 & 34 & H & 16 & 109 & 3 & 1 & 0 \\
\hline $73 / 11 / 20$ & 0.70 & 2 & H & 16 & 109 & 3 & 3 & 0 \\
\hline $73 / 11 / 29$ & 0.95 & 33 & H & 16 & 109 & 2 & 1 & 0 \\
\hline $73 / 12 / 21$ & 1.10 & 2 & H & 17 & 204 & 3 & 2 & 0 \\
\hline $74 / 1 / 15$ & 1.65 & 57 & H & 15 & 102 & 0 & 3 & 1 \\
\hline $74 / 1 / 16$ & 1.80 & 55 & H & 12 & 122 & 2 & 1 & 5 \\
\hline $74 / 1 / 30$ & 2.30 & 45 & H & 20 & 136 & 0 & 1 & 4 \\
\hline $74 / 2 / 7$ & 2.10 & 7 & H & 14 & 95 & 2 & 0 & 0 \\
\hline $74 / 4 / 27$ & 2.55 & 50 & H & 12 & 82 & 4 & 0 & 0 \\
\hline $74 / 12 / 5$ & 0.95 & 27 & $H$ & 15 & 102 & 2 & 3 & 0 \\
\hline $74 / 12 / 27$ & 1.10 & 23 & $P$ & 1 & 7 & 0 & 0 & 0 \\
\hline $74 / 12 / 28$ & 1.10 & 31 & $H$ & 3 & 20 & 0 & 1 & 0 \\
\hline $74 / 12 / 30$ & 1.05 & 13 & H & 10 & 75 & 0 & 0 & 0 \\
\hline $75 / 1 / 24$ & 1.12 & 15 & H & 8 & 54 & 2 & 1 & 0 \\
\hline $75 / 2 / 13$ & 1.60 & 30 & H & 13 & 88 & 1 & 0 & 0 \\
\hline $75 / 2 / 14$ & 1.65 & 28 & H & 15 & 102 & 0 & 2 & 0 \\
\hline $75 / 12 / 3$ & 1.20 & 64 & $P$ & 1 & 9 & 0 & 1 & 0 \\
\hline $75 / 12 / 5$ & 1.45 & 74 & $\mathrm{H}$ & 12 & 82 & 0 & 3 & 2 \\
\hline $75 / 12 / 10$ & 1.65 & 62 & H & 13 & 88 & 1 & 0 & 0 \\
\hline $75 / 12 / 31$ & 1.60 & 30 & $H$ & 12 & 82 & 0 & 3 & 0 \\
\hline $76 / 1 / 16$ & 1.65 & 10 & H & 16 & 109 & 1 & 2 & 0 \\
\hline $76 / 1 / 16$ & 1.65 & 10 & p & 1 & 7 & 0 & 0 & 0 \\
\hline $76 / 2 / 19$ & 2.00 & 14 & $\mathrm{P}$ & 1 & 7 & 0 & 0 & 0 \\
\hline $76 / 2 / 20$ & 1.95 & 5 & $H$ & 16 & 109 & 1 & 2 & 0 \\
\hline $76 / 2 / 27$ & 2.08 & 22 & H & 15 & 102 & 0 & 1 & 1 \\
\hline $76 / 3 / 4$ & 1.95 & 0 & H & 12 & 82 & 1 & 2 & 0 \\
\hline $76 / 12 / 22$ & 0.70 & 2 & H & 16 & 54 & 2 & 0 & 0 \\
\hline $77 / 1 / 20$ & 0.90 & 16 & $\mathrm{P}$ & 1 & 7 & 0 & 1 & 0 \\
\hline $77 / 1 / 20$ & 0.90 & 16 & H & 16 & 54 & 3 & 0 & 0 \\
\hline $77 / 3 / 8$ & 1.10 & 13 & P & 1 & 7 & 1 & 0 & 0 \\
\hline $77 / 3 / 9$ & 1.12 & 18 & H & 16 & 77 & 0 & 4 & $\begin{array}{l}0 \\
0\end{array}$ \\
\hline $77 / 4 / 1$ & 1.35 & 4 & H & 22 & 95 & 1 & 2 & 0 \\
\hline $77 / 12 / 4$ & 1.05 & 24 & $H$ & 12 & 82 & 1 & 3 & 0 \\
\hline $77 / 12 / 22$ & 1.10 & 0 & H & 14 & 28 & 0 & 1 & 0 \\
\hline $78 / 1 / 5$ & 1.40 & 24 & H & 14 & 28 & 2 & 0 & 0 \\
\hline $78 / 2 / 4$ & 1.35 & 18 & $P$ & 4 & 27 & 3 & 1 & 0 \\
\hline $78 / 3 / 13$ & 1.45 & 13 & H & 17 & 34 & 3 & 0 & 0 \\
\hline $78 / 3 / 13$ & 1.45 & 13 & P & 4 & 27 & 0 & 0 & 0 \\
\hline $78 / 3 / 18$ & 1.50 & 9 & $P$ & 4 & 27 & 1 & 2 & 0 \\
\hline $78 / 3 / 27$ & 1.65 & 30 & H & 6 & 12 & 4 & 0 & 0 \\
\hline $78 / 12 / 22$ & 0.85 & 15 & H & 15 & 30 & 3 & 2 & 0 \\
\hline $78 / 12 / 22$ & 0.85 & 15 & $P$ & 3 & 20 & 0 & 1 & 1 \\
\hline
\end{tabular}




\begin{tabular}{|c|c|c|c|c|c|c|c|c|}
\hline $\begin{array}{c}\text { Date } \\
\text { (year, month } \\
\text { day) }\end{array}$ & $\begin{array}{l}\text { Total snow } \\
\text { stake } \\
(\mathrm{m}) \star\end{array}$ & $\begin{array}{l}\text { 3-day precipi- } \\
\text { tation history } \\
\qquad(\mathrm{m})\end{array}$ & $\begin{array}{l}\text { Type of } \\
\text { control } \\
\star \star \star \\
\end{array}$ & $\begin{array}{c}\text { Number of } \\
\text { bombs }\end{array}$ & $\begin{array}{l}\text { Total mass of } \\
\text { explosives } \\
(\mathrm{kg})\end{array}$ & size 2 & $\begin{array}{l}\text { mber of } \\
\text { lanches } \\
\text { size } 3\end{array}$ & $\begin{array}{l}\text { va- } \\
\text { size } 4\end{array}$ \\
\hline $78 / 12 / 26$ & 0.92 & 9 & $P$ & 1 & 7 & 0 & 1 & 0 \\
\hline $79 / 2 / 9$ & 1.25 & 14 & $\mathrm{p}$ & 4 & 27 & 0 & 1 & 0 \\
\hline $79 / 2 / 12$ & 1.45 & 25 & p & 3 & 20 & 0 & 2 & 0 \\
\hline $79 / 2 / 14$ & 1.55 & 31 & H & 26 & 52 & 2 & 4 & 0 \\
\hline $79 / 2 / 27$ & 1.62 & 27 & H & 8 & 16 & 1 & 0 & 0 \\
\hline $79 / 4 / 6$ & 1.70 & 12 & $\ddot{p}$ & 4 & 27 & 0 & 0 & 0 \\
\hline $79 / 4 / 17$ & 1.73 & 11 & p & 1 & 7 & 0 & 0 & 0 \\
\hline $79 / 4 / 18$ & 1.90 & 33 & H & 20 & 40 & 2 & 1 & 0 \\
\hline $79 / 12 / 8$ & 0.93 & 9 & p & 4 & 27 & 0 & 0 & 0 \\
\hline $79 / 12 / 14$ & 1.40 & 45 & p & 1 & 7 & 1 & 0 & 0 \\
\hline $79 / 12 / 15$ & 1.70 & 65 & H & 14 & 48 & 0 & 0 & 0 \\
\hline $79 / 12 / 18$ & 1.60 & 41 & H & 33 & 66 & 0 & 0 & 0 \\
\hline $80 / 2 / 22$ & 1.70 & 6 & $\mathrm{H}$ & 15 & 15 & 0 & 0 & 0 \\
\hline $80 / 3 / 10$ & 1.75 & 15 & $p$ & 4 & 27 & 0 & 1 & 0 \\
\hline $80 / 3 / 14$ & 2.08 & 30 & P & 1 & 7 & 0 & 0 & 0 \\
\hline $80 / 3 / 14$ & 2.08 & 30 & H & 26 & 86 & 3 & 2 & 0 \\
\hline $80 / 3 / 18$ & 2.08 & 12 & p & 1 & 7 & 0 & 0 & 0 \\
\hline $80 / 3 / 20$ & 2.03 & 16 & H & 17 & 70 & 2 & 1 & 1 \\
\hline $80 / 4 / 15$ & 1.92 & 4 & p & 1 & 7 & 0 & 0 & 0 \\
\hline $80 / 4 / 20$ & 1.78 & 1 & p & 1 & 7 & 0 & 0 & 0 \\
\hline $80 / 4 / 23$ & 1.75 & 4 & P & 1 & 7 & 1 & 0 & 0 \\
\hline $80 / 4 / 23$ & 1.75 & 4 & H & 4 & 20 & 0 & 1 & 0 \\
\hline $80 / 11 / 22$ & 0.90 & 53 & $\mathrm{H}$ & 6 & 28 & 1 & 1 & 0 \\
\hline $80 / 12 / 4$ & 1.20 & 44 & p & 5 & 20 & 0 & 1 & 0 \\
\hline $80 / 12 / 4$ & 1.20 & 44 & $\mathrm{H}$ & 5 & 30 & 0 & 0 & 0 \\
\hline $80 / 12 / 15$ & 1.10 & 8 & p & 3 & 12 & 1 & 0 & 0 \\
\hline $80 / 12 / 26$ & 1.42 & 29 & p & 2 & 8 & 0 & 0 & 0 \\
\hline $80 / 12 / 27$ & 1.42 & 27 & p & 2 & 8 & 0 & 0 & 0 \\
\hline $80 / 12 / 28$ & 1.55 & 41 & $\mathrm{H}$ & 13 & 62 & 1 & 3 & 0 \\
\hline $81 / 2 / 15$ & 1.42 & 1 & $p$ & 3 & 12 & 1 & 1 & 0 \\
\hline $81 / 2 / 16$ & 1.53 & 8 & P & 2 & 8 & 1 & 0 & 0 \\
\hline $81 / 2 / 18$ & 1.58 & 24 & $\mathrm{p}$ & 2 & 8 & 1 & 0 & 0 \\
\hline $81 / 2 / 20$ & 1.73 & 18 & P & 4 & 16 & 0 & 0 & 0 \\
\hline $81 / 2 / 21$ & 1.73 & 15 & $\mathrm{H}$ & 16 & 32 & 2 & 2 & 0 \\
\hline $81 / 3 / 6$ & 1.75 & 14 & p & 3 & 12 & 0 & 0 & 0 \\
\hline $81 / 4 / 8$ & 1.80 & 14 & $\mathrm{H}$ & 14 & 34 & 1 & 0 & 0 \\
\hline $81 / 4 / 16$ & 1.82 & 4 & $p$ & 2 & 8 & 1 & 0 & 0 \\
\hline $81 / 4 / 16$ & 1.82 & 4 & H & 6 & 17 & 1 & 0 & 0 \\
\hline $81 / 4 / 17$ & 1.82 & 6 & p & 2 & 8 & $i$ & 0 & 0 \\
\hline $81 / 12 / 11$ & 1.03 & 9 & $p$ & 2 & 8 & 0 & 2 & 0 \\
\hline $81 / 12 / 11$ & 1.03 & 9 & H & 17 & 36 & 2 & 5 & 0 \\
\hline $82 / 1 / 26$ & 1.60 & 37 & $\mathrm{p}$ & 7 & 28 & 2 & 2 & 1 \\
\hline $82 / 1 / 26$ & 1.60 & 37 & $H$ & 9 & 18 & 0 & 5 & 1 \\
\hline $82 / 2 / 2$ & 1.73 & 10 & $\mathrm{H}$ & 14 & 28 & 2 & 4 & 0 \\
\hline $82 / 2 / 15$ & 2.00 & 27 & $\mathrm{H}$ & 16 & 32 & 2 & 2 & 0 \\
\hline $82 / 3 / 12$ & 2.00 & 6 & p & 6 & 24 & 1 & 0 & 0 \\
\hline $82 / 3 / 15$ & 2.25 & 30 & P & 7 & 28 & 0 & 0 & 0 \\
\hline $82 / 3 / 22$ & 2.05 & 2 & $H$ & 22 & 50 & 0 & 0 & 0 \\
\hline
\end{tabular}

Total snow depth at a level study plot at elevation $2200 \mathrm{~m}$, and located within $5 \mathrm{kr}$ of starting zones at elevation 2500 to $3000 \mathrm{~m}$.

** Sum of all water equivalents of snow over 3-day period preceding mission, and measured at level study plot as in footnote*.

*** $H$ is helicopter-bombing mission; $P$ is radio detonation of preplanted explosive. 